Sains Malaysiana 47(11)(2018): 2811-2820

http://dx.doi.org/10.17576/jsm-2018-4711-24

\title{
Olive and Its Phenolic Compound as the Promising Neuroprotective Agent
}

(Sebatian Fenolik di dalam Buah Zaitun Berpotensi sebagai Agen Perlindungan Saraf)

\author{
KHIDHIR KAMIL, JAYA KUMAR, MUHAMMAD DAIN YAZID \& RUSZYMAH BINTI HAJI IDRUS*
}

\begin{abstract}
Recent progress in alternative medicine has highlighted the benefits of olive as an integral part of therapeutic diet to promote healthy living. Among the thirty different phenolic compounds of olive known to date; oleocanthal, oleuropein, tyrosol and hydroxytyrosol are being increasingly investigated for their potential in prevention and healing of several major forms of neurological dysfunctions and disorders. A considerable amount of literature suggests the neuroprotective effects of olive and its phenolic compounds are owing to their roles as anti-oxidant, anti-inflammatory and anti-apoptotic agents. At preclinical level, olive attenuated cognitive dysfunctions and the functional outcomes in spinal cord injury, delayed the progression of amyloid beta pathology, improved motor and mitochondrial dysfunctions in Parkinson's disease, reversed diabetic-related neurological complications and also ameliorated cerebral pathologies in stroke. In this paper, we aim to review the neuroprotective role of olive and its phenolic derivatives in the following diseases or deficits of the nervous system that include cognitive dysfunction, neurodegenerative diseases, stroke, peripheral neuropathy and spinal cord injury.
\end{abstract}

Keywords: Neuroprotection; neurodegeneration; neuropathy; nerve; olive; Olea europaea

\section{ABSTRAK}

Perkembangan terkini dalam perubatan alternatif telah membuktikan khasiat buah zaitun sebagai bahan penting dalam diet yang menggalakkan gaya hidup sihat. Antara tiga puluh sebatian fenolik yang terdapat di dalam buah zaitun; oleocantal, oleuropein, tirosol dan hidroksitirosol telah dikaji dengan kerap akan potensinya dalam mencegah dan merawat beberapa penyakit berkaitan saraf. Beberapa kajian telah mengesyorkan keupayaannya dalam memberi perlindungan adalah disebabkan oleh fungsinya sebagai anti-oksidan, anti-radang dan anti-apoptosis. Kesan zaitun ke atas perlindungan sistem saraf masih belum diterokai sepenuhnya pada peringkat ujian klinikal setakat ini. Manakala pada peringkat pra-klinikal pula, buah zaitun mampu memperbaiki fungsi kognitif otak, mengurangkan komplikasi akibat daripada kecederaan saraf tunjang, melambatkan kesan patologi oleh protein amiloid beta, memperbaiki fungsi motor dan mitokondria dalam penyakit Parkinson, merawat komplikasi penyakit diabetes dan mengurangkan kerosakan tisu kepada otak semasa strok. Dalam kertas ini, kesan perlindungan buah zaitun dalam kategori penyakit seperti berikut: kerosakan fungsi kognitif, penyakit neurodegeneratif, strok, periferal neuropati dan kecederaan saraf tunjang akan didalami.

Kata kunci: Buah zaitun; neurodegeneratif; neuropati; Olea europaea; perlindungan saraf; saraf

\section{OLIVE AND ITS PHENOLIC COMPOUND:} ANTI-OXIDANT POTENTIAL

Oxidative stress is a well known contributing factor in development of various disease (Kumar et al. 2017; Matough et al. 2012). Recent developments in phytomedicine have reported various health-improving effects of numerous plant extracts (Budin et al. 2009; Esmaeili et al. 2016; Ruszymah et al.2012). Olive, or also known as Olea europaea is a native tree commonly found in Mediterranean region (El \& Karakaya 2009). Generally, olive trees are cultivated for oil, leaf extracts and fruits. Olive oil consists primarily of triacylglycerols ( $99 \%)$, free fatty acids and lipids such as hydrocarbons, sterols, aliphatic alcohol, tocopherols and pigments (Boskou et al. 2006). At least 30 different phenolic compounds have been found to originate from the olive that include oleuropein, tyrosol and hydroxytyrosol (Parkinson \& Cicerale 2016). Most of these phenolic compounds were reported to have anti-oxidant potential (Aghagolzadeh et al. 2017; De La Cruz et al. 2010; Pourkhodadad et al. 2016). More specifically, oleuropein, one of the aforementioned phenolic compounds, prevents free radical formation through chelation of metal ions such as copper and iron, which catalyse the generation of free radicals (Assimopoulou et al. 2002). Hydroxytyrosol (HT) nullified free radicals by forming intramolecular bond with radicals through donation of a hydrogen ion (Visioli \& Galli 1998). Recent reports from the European Food Safety Authority have backed the anti-oxidant potential of HT against LDLinduced oxidative damage with specific recommendation of dietary dosage as supplemental in diet (EFSA 2011). In addition, tyrosol reduced reactive oxygen and nitrogen 
species such as nitric oxide in Parkinson's disease (PD) model of rats (Dewapriya et al. 2013).

The neuroprotective effects of olive oil or its components have been proven in various neurological disorders. Considering the widespread etiology and pathophysiology of these disorders, we have restricted our focus on cognitive dysfunction, neurodegenerative diseases, ischaemic reperfusion brain injury (stroke), peripheral neuropathy and spinal cord injury in this review to elucidate the neuroprotective roles of olive and its phenolic compounds.

\section{NEUROPROTECTIVE EFFECTS OF OLIVE IN COGNITIVE DYSFUNCTION}

Cognition is a higher mental process that enable humans to 'acquire knowledge and understand through thought, experience and senses' (Oxford Dictionaries 2018). Such high order process involves thinking, memory, judgement, evaluation, perception of surroundings, attention, reasoning, planning, decision making and comprehension (Bisson et al. 2015). Cognitive dysfunction is precipitated through aging and various pathologies such as Alzheimer's disease $(\mathrm{AD})$, brain trauma and post-traumatic stress. To date, several studies have suggested the olive to prevent and even delay the progression of various cognitive deficits.

In the PREDIMED study, 578 participants that was undergoing Mediterranean diet with olive oil for 5 years, were exposed to various neuropsychological tests to assess their cognitive functions. To the authors' surprise, elderly participants with high cardiovascular risk performed well in the assigned cognitive tests which led the authors to surmise that consumption of foods rich in polyphenols such as olive oil in particular, can improve cognitive functions even among the older population (Valls-Pedret et al. 2012). Laboratory experiments showed the olive oil to modify gene and microRNA (miRNA) expression profiles associated with aging (Luceri et al. 2017). In addition, phenolic-rich extra virgin olive oil (H-EVOO) treatment upregulated the expression of genes associated with synaptic plasticity such as Notch1, BMP, NGFR, GLPIR, Myst3 and CRCTC3 in aged mice. Intriguingly, the aged mice treated with H-EVOO displayed a similar miRNA expression profiles at the cortex of that young mice. Conversely, the aged mice treated with phenolicdeficient extra virgin olive (L-EVOO) showed increased miRNA expressions of miR-29 and miR-34 (associated with aging and $\mathrm{AD}$ ). Furthermore, when tested in mnemonic and motor coordination paradigms, the aged mice treated with H-EVOO performed better than the aged L-EVOO treated group, suggesting the centrality of phenolic compounds in mediating the effects of olive oil in improving the cognitive and motor functions (Luceri et al. 2017).

In line with these findings, one of the phenolic compounds of olive, oleuropein was shown to be neuroprotective in a rat model of post-traumatic stress disorder (PTSD). In this study, the rats were exposed to a single prolonged stress (SPS) (series of validated tests done to induce traumatic experience in rats to mimic human PTSD condition) and were given oleuropein 20,50 and $100 \mathrm{mg} /$ $\mathrm{kg}$ intraperitoneally for 21 consecutive days. Oleuropein reversed the SPS-induced cognitive impairment and also the downregulation of brain-derived neurotrophic factor (BDNF) (a growth factor that is important in neuronal growth and survival) (Lee et al. 2017). In addition to PTSD model, oleuropein also dramatically improved the learning and memory retention of pharmacological rat model of cognitive dysfunction, where the cognitive decline was induced by colchicine infusion at the hippocampal CA1 area (Pourkhodadad et al. 2016).

\section{NEUROPROTECTIVE EFFECTS OF OLIVE IN NEURODEGENERATIVE DISEASES}

Neurodegenerative disease is a spectrum of disorders that involves progressive destruction of structure, integrity and function of neurons that ultimately lead to neuronal death (Brown et al. 2005). Alzheimer's disease (AD) and Parkinson's disease (PD) are the most commonest neurodegenerative diseases to plague millions of older population around the globe. As these diseases are incurable to date, recent researches have explored a new set of potential therapies involving natural products to manage these diseases.

Amyloid plaques and neurofibrillary tangles are two brain abnormalities that define $\mathrm{AD}$. The primary component of amyloid plaques is amyloid beta $(A \beta)$. Accumulation of $A \beta$ leads to neurodegeneration and the mental deterioration notably seen among the AD patients. In the pathogenesis of $\mathrm{AD}, \mathrm{A} \beta$ clearance usually involves apolipoprotein E (ApoE)-dependent pathway that comprises of ATPbinding cassette transporter ABCA1 protein in regards to their role in regulating cellular cholesterol (promote endocytosis and lysosomal degradation of $A \beta$ ) and stabilising toxic $A \beta$ oligomers (Cerf et al. 2011; Lee et al. 2012). Administration of extra-virgin olive oil (EVOO) has been shown to enhance $\mathrm{A} \beta$ clearance in the $\mathrm{AD}$ mice model. EVOO increased the expression of ApoE and ABCA1 proteins through modulation of their regulatory receptors, peroxisome proliferator-activated receptor gamma and liver X-receptors. Hyperphosphorylation of tau (proteins that stabilises microtubules) can result in the formation of neurofibrillary tangles and subsequent neurodegeneration. EVOO also reduced the hyperphosphorylation of tau proteins in the mice AD model (Qosa et al. 2015).

The neuroprotective effects of olive was further corroborated through oleocanthal, another phenolic compound of olive. Oleocanthal attenuated toxic amyloid beta oligomers $(\mathrm{A} \beta \mathrm{O})$-induced neuroinflammatory response by reducing IL- 6 and reversing the A $\beta$ oinduced down-regulation of glutamate transporter-1, a neurosupportive protein in astrocytes) (Batarseh et al. 2017). Moreover, in a separate study, microinjections of oleuropein and $\mathrm{A} \beta 42$ aggregate into the rat nucleus basalis magnocellularis (NBM) formed a completely non-toxic growth aggregates, which was unlike the injection of toxic 
A $\beta 42$ aggregate alone. Further laboratory investigations showed $A \beta$ aggregates grown in the presence of OLP not to show any tendency to disassemble and undergo toxic oligomerisation, suggesting the potential role of OLP in hampering the formation of toxic $\mathrm{A} \beta$ aggregates (Luccarini et al. 2014).

The findings on neuroprotective effects of olive were extended to various animal models of Parkinson's disease (PD) as well (Aghagolzadeh et al.2017). Olive leaf extract (OLE) improved the motor deficits induced by intrastriatal injections of 6-OHDA to rats (chemically induced PD in rats) in various behavioural paradigms such as rotational test, narrow beam test and grip strength test. OLE also attenuated the subcutaneuous rotenone-induced PD-like motor dysfunction and weakness in rats which appears to be mediated by increased in anti-oxidant activities and reduced free radicals generation (Sarbishegi et al. 2018).

Several in vitro models have elucidated the mechanistic effects of phenolic compounds of olive oil in PD. Parkinsonian toxin, 1-methyl-4-78 phenylpyridinium (MPP+), is a commonly used drug to cause neuronal death through induction of mitochondrial dysfunction in dopaminergic cells, particularly in the substantia nigra (Lotharius \& Malley 2000). Tyrosol was shown to reverse the MPP+-induced mitochondrial dysfunction and decrease in intracellular ATP generation in CATH.a cells. Furthermore, tyrosol also up-regulated the expression of anti-apoptotic proteins, Bcl-2 ad Bcl-xl to counteract against the pro-apoptotic proteins, Bax and BID (Dewapriya et al.2013). Conversely, hydroxytyrosol, another phenolic component of olive had no apparent effect on MPP+ induced cytotoxicity in SH-SY5Y cells. However, HT was able to express its neuroprotection against 6-OHDAinduced cell death in the same cell line (Yu et al. 2016). It is likely that different cell lines may have varied response to cytotoxicity induced by MPP+ and 6-OHDA. Therefore, more experiments should be carried out to elucidate this discrepancy.

\section{NEUROPROTECTIVE EFFECTS OF OLIVE IN ISCHEMIA-} REPERFUSION (STROKE) MODEL

Anumber of investigators have reported the neuroprotective effects of olive oil in rodent models of ischaemic reperfusion brain injury (Hassanshahi et al. 2013; Mardookhi et al. 2016). Olive oil reduced cellular apoptosis in ischaemic mice by increasing the expression of anti-apoptotic protein, bcl2 in the hippocampus (Hassanshahi et al. 2013). In a follow up study, mice pretreated with olive oil $(0.75 \mathrm{~mL} / \mathrm{kg} /$ day) for a month prior to middle cerebral artery occlusion, showed reduced infarct volume in total brain hemisphere, cortex and striatum and also exhibited better neurologic defect score compared to the ischaemic group. Molecular findings showed the neuroprotective effects of the olive oil could be owing to its interaction with NF- $\kappa \beta$ and tumor necrosis factor receptor 1 (TNFR1) (Mardookhi et al. 2016).

Apart from damaging the brain cells, occlusion of cerebral vessels also could deteriorate the integrity of the blood vessels. Loss of vascular structural integrity will result in destruction of blood brain barrier (BBB) and would further aggravate the pathology by causing cerebral edema. Evans blue (EB) dye is a good tool for assessing the permeability of BBB due to its macrostructure (Banks et al. 2000) and high affinity for albumin (Wolman et al. 1981). A number of studies have assessed the effects of olive treatment on the integrity of BBB using EB. Significant reduction in extravasation of $\mathrm{EB}$ in brain tissue and also brain water content was observed in ischaemic rats following the administration of OLE (Mohagheghi et al. 2011). In a separate study, oleuropein reversed the bilateral common carotid artery occlusion and reperfusion-induced decrease in arteriolar diameter, increase in microvascular leakage and leukocyte adhesion to venules and reduction in capillary perfusion (Mastantuono et al. 2015). Thus, oleuropein is potentially a promising candidate to reduce secondary injury to the brain as a result of stroke.

In stroke, development of occlusion in the cerebral vessel was mostly caused by the formation of atherosclerotic plaque. High low-density lipoprotein (LDL) and low highdensity lipoprotein (HDL) levels are the leading causes for increased risk of atherosclerotic plaque formation. In the EUROLIVE randomized trial done in 2006, olive increased the levels of HDL, decreased total cholesterol-HDL ratio and LDL-HDL ratio (Poulsen et al. 2006). The severity of tissue damage from ischaemic insult can also be measured through the levels of lactate dehydrogenase (LDH) efflux in vitro (González-Correa et al. 2008). During the hypoxic stage, brain LDH level increases, whereas during the reoxygenation process, the $\mathrm{LDH}$ level drops. In the study conducted by González-Correa et al. (2008), the rats treated with virgin olive oil (VOO) for 7 days were subjected to hypoxia-reoxygenation and followed by assessment of LDH efflux. VOO which contains high levels of HT and HT-acetate, were found to reduce the LDH level during the hypoxic condition in a dose-dependent manner.

\section{NEUROPROTECTIVE EFFECT OF OLIVE IN PERIPHERAL NEUROPATHY}

Peripheral neuropathy is characterised by manifestations of physical symptoms such as tingling sensations, numbness, weakness and pain that are commonly attributed to type2 diabetes mellitus (Chawla et al. 2016). Streptozotocin (STZ)-induced diabetes is one of the consensually accepted models for diabetic neuropathy in rats. STZ-induced diabetic rats are validated through their significant impairment of nerve conduction velocity (NCV), sciatic $\mathrm{Na}^{+}, \mathrm{K}^{+}$-ATPase activity (to measure structure or function of large myelinated fibers), thermal nociceptive threshold and mechanical nociceptive tolerance (as indicators of neuropathic pain), plasma thiobarbituric acid-reactive substances (TBARS, as indicator of oxidative stress). HT reversed most of these impairments, with significant improvements in thermal response latency, suggesting its protective role in diabetic neuropathy (Ristagno et al. 2012). In 2012, Ristagno et al. reported HT to significantly reduce 


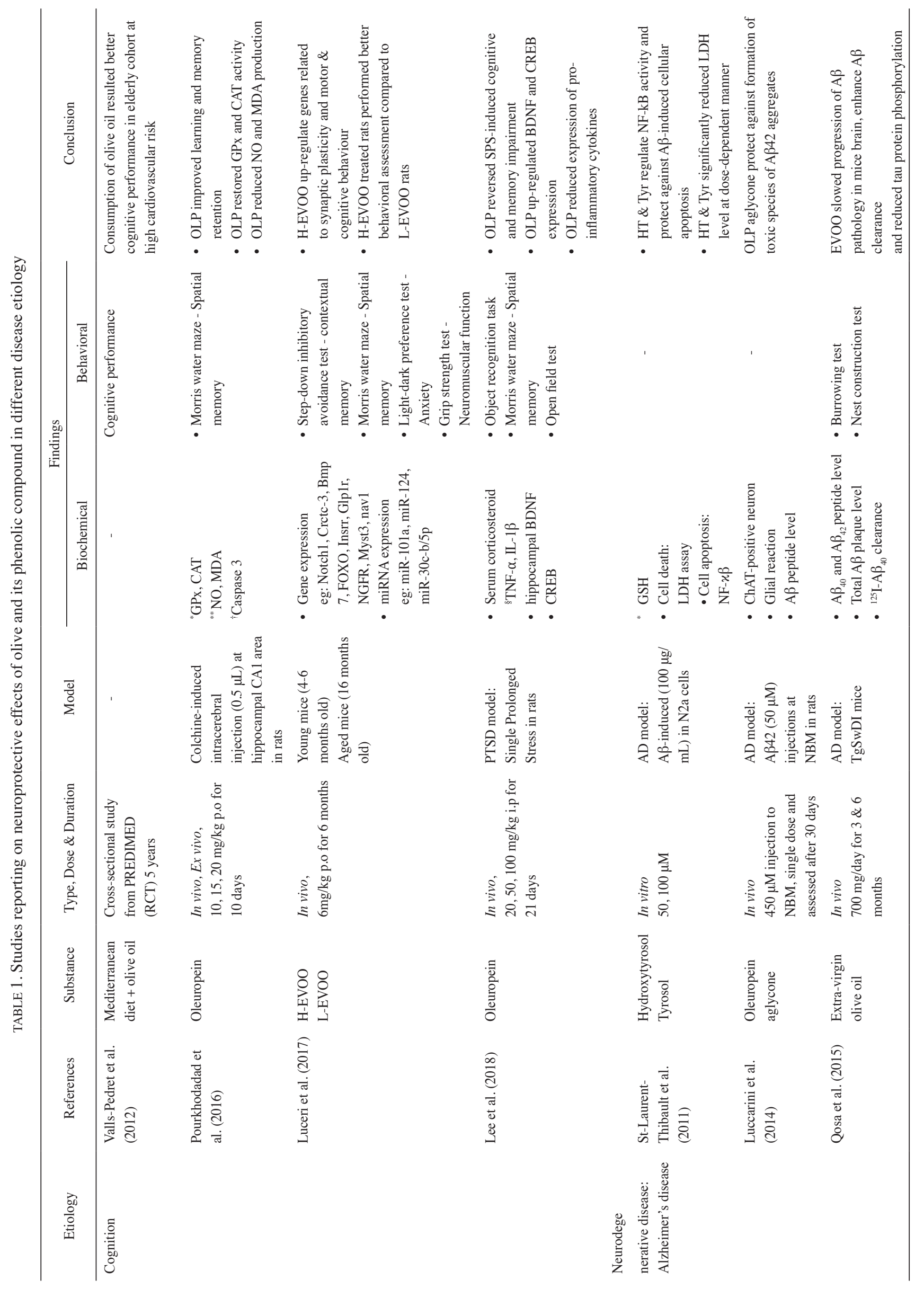




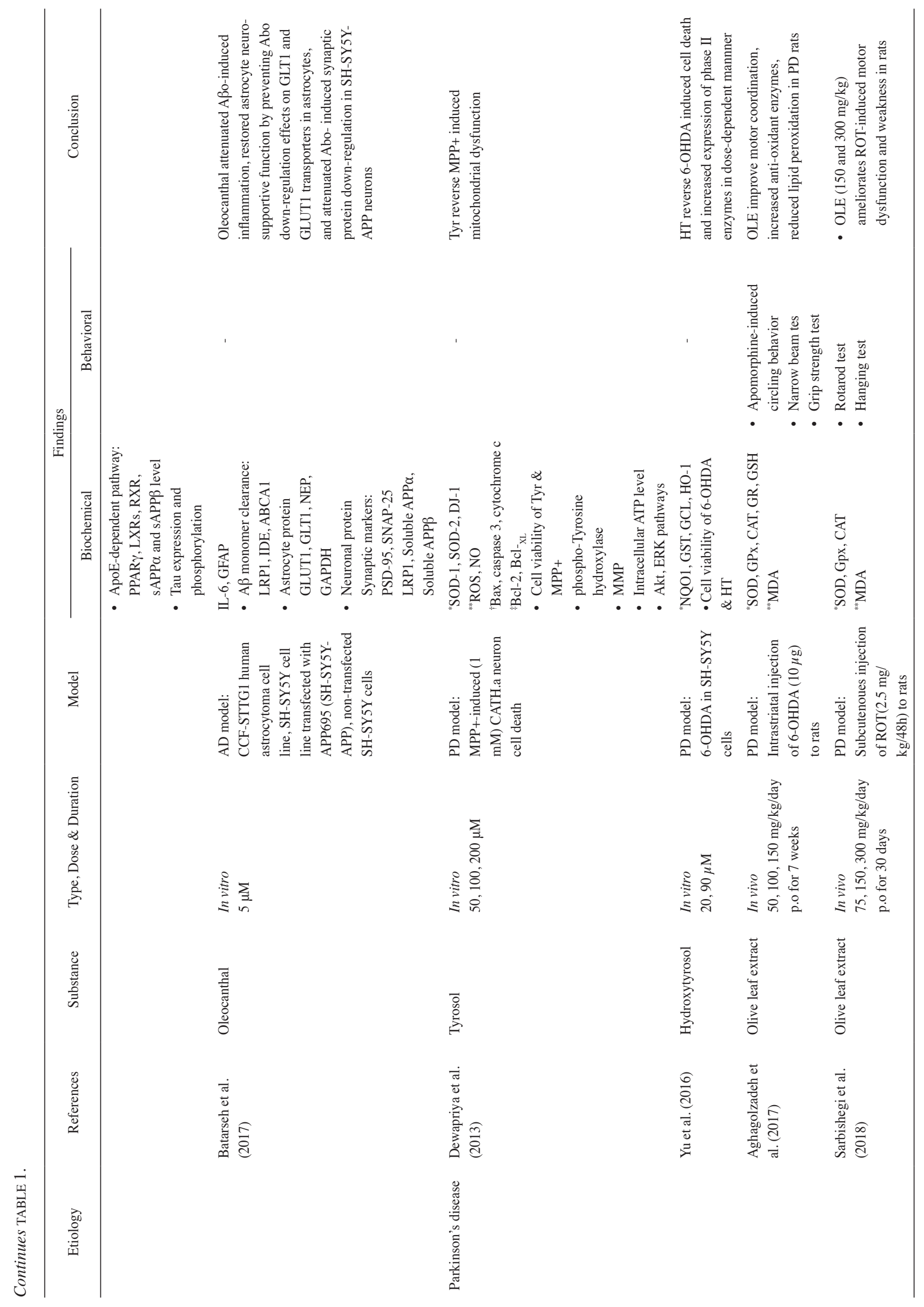




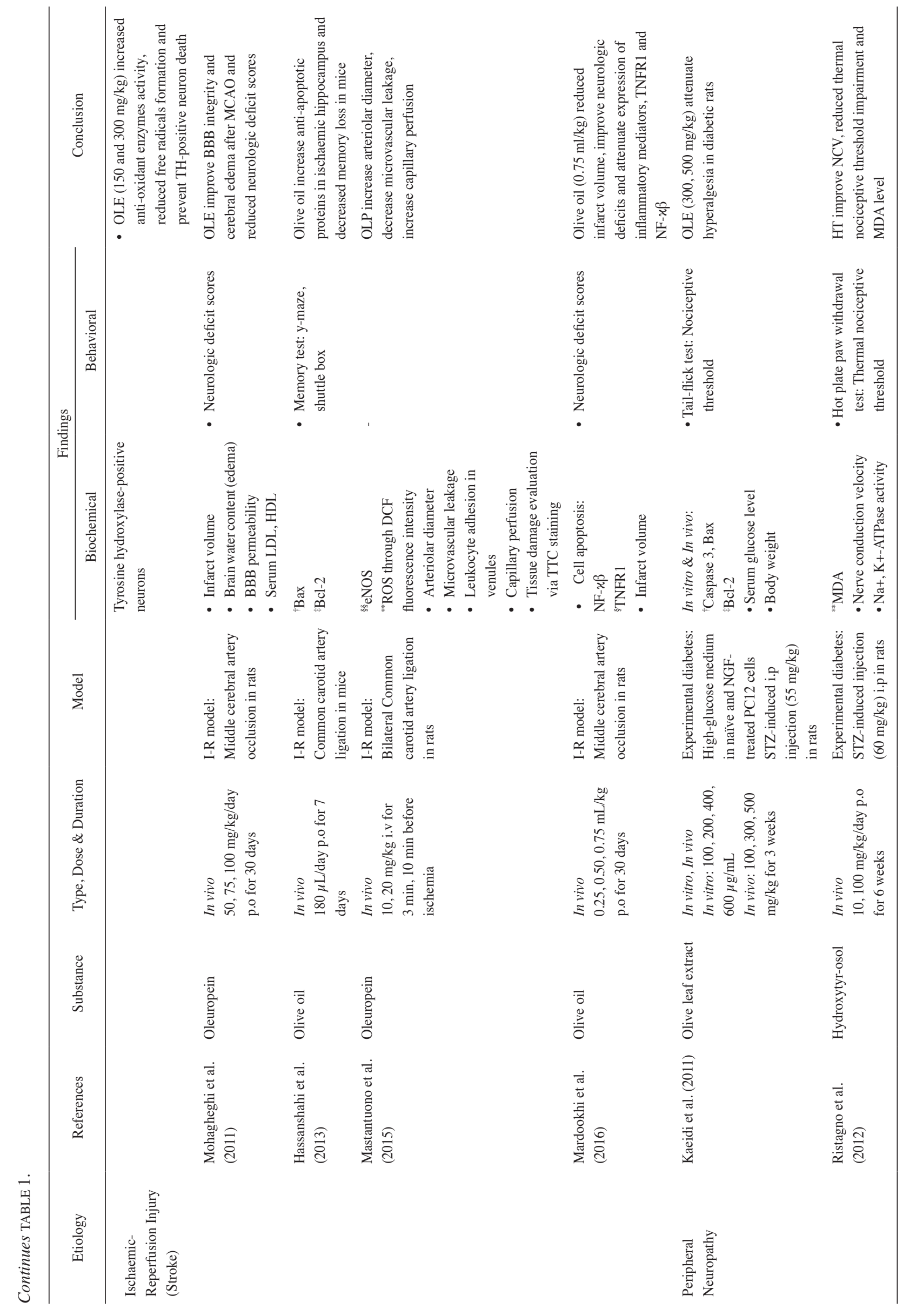




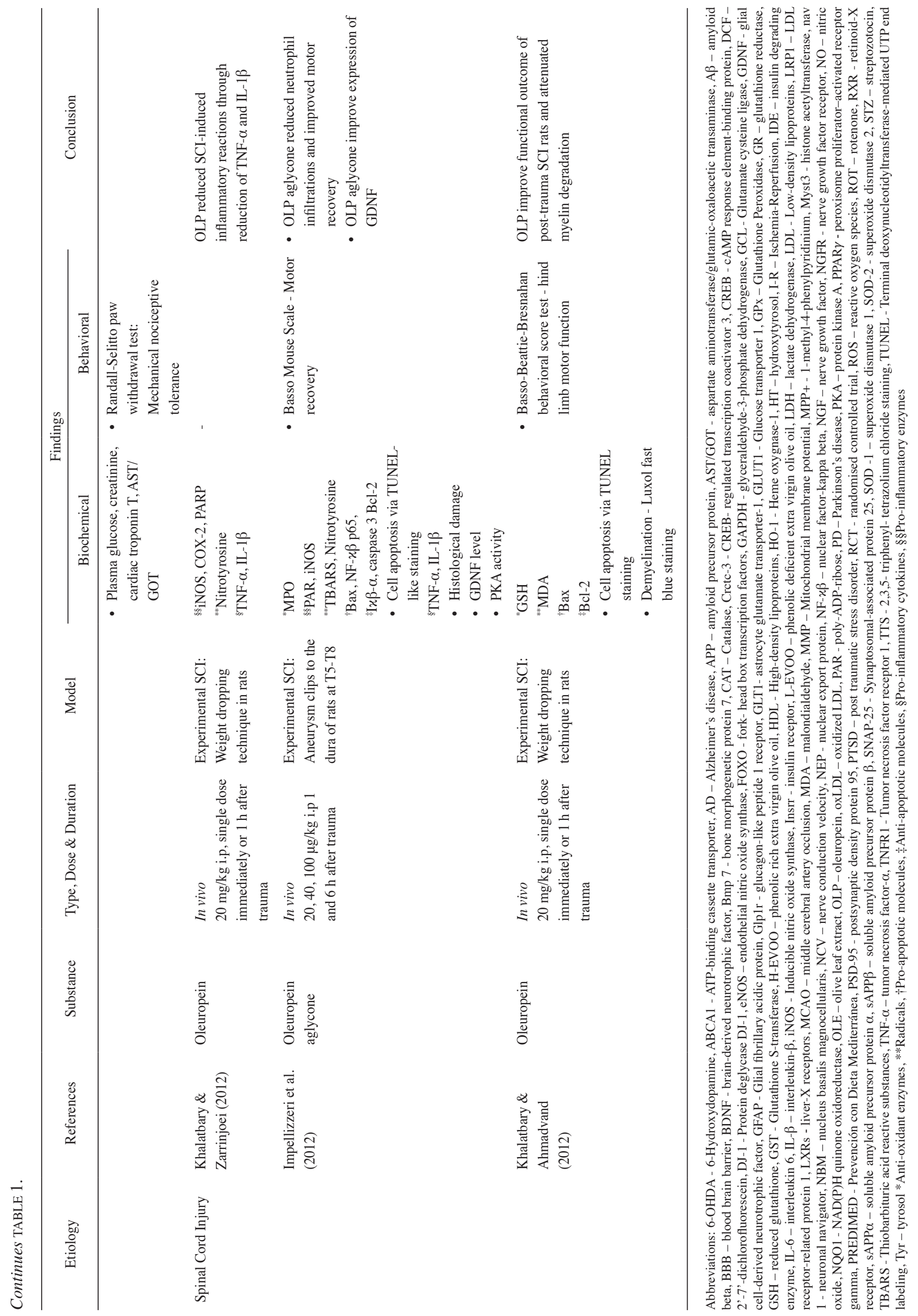


diabetic-induced thermal hypoalgesia by approximately $34 \%$ in diabetic rats. The authors speculated that the attenuating effect towards thermal hyperalgesia seen was probably due to HT protection against degeneration of skin nerve fibers (Leonelli et al. 2007; Ristagno et al. 2012). In addition, administration of olive leaf extract (OLE) (300 and $500 \mathrm{mg} / \mathrm{kg}$ ) to STZ-induced diabetic rats also significantly improved the tail flick latency (test to indicate pain response in rats). In the same study, OLE also profoundly decreased the hyperglycemia-induced activation of caspase 3 (denotes pro-apoptotic state) and other pro-apoptotic markers such as Bax, which propose that the amelioration of diabetic neuropathy in STZ-induced rats by OLE may be mediated by its anti-apoptotic potential (Kaeidi et al. 2011).

\section{NEUROPROTECTIVE EFFECT OF OLIVE IN SPINAL CORD INJURY}

Mechanical injury is often followed by series of inflammatory reactions, which in case of spinal injury could damage the non-regeneratable spinal tissues. Intraperitoneal administration of oleuropein $(20 \mathrm{mg} / \mathrm{kg})$ to rats following contusive spinal injury significantly reduced the inflammation-induced rise in expression of TNF- $\alpha$ and IL-1 $\beta$ (Khalatbary \& Zarrinjoei 2012) via inhibition of NF- $\kappa \beta$ and MAPK signaling-associated pathways (Feng et al. 2017). Follow up study on the injured rats showed oleuropein $(20 \mathrm{mg} / \mathrm{kg})$ to significantly improve the motor recovery of the rats (Khalatbary \& Zarrinjoei 2012). Similar findings were also reported by Impellizzeri et al. (2012) where the researchers showed intraperitoneal injection of oleuropein aglycone $(20,40$, $100 \mu \mathrm{g} / \mathrm{kg}$ ) to improve the spinal cord injury-induced motor deficits.

\section{CONCLUSION}

Myriad of studies have reported neuroprotective potential of olive oil and its phenolic compounds in various in vivo and in vitro models of neurological disorders. The neuroprotective effects of olive and its derivatives are seem to be attributed to its anti-inflammatory, anti-oxidant and anti-apoptotic properties. Existing literature has thrown up numerous questions in need of further investigations such as the influence of olive on NF- $\kappa \beta$ and TNFR1 in ischaemic injury, the mechanism of interaction between the phenolic compounds of olive and various pro- and anti-apoptotic proteins in neuroinflammation and the exact role of olives in innate anti-oxidant system. Therefore, more research is needed to elucidate the neuroprotective mechanism of olive and its components. There are no conflicting interests among the authors.

\section{REFERENCES}

Aghagolzadeh, M., Moghaddam, A. \& Seyedalipour, B. 2017. Olive leaf extract reverses the behavioral disruption and oxidative stress induced by intrasrtiatal injectioin of 6-hydroxydopamine in rats. Physiology and Pharmacology 21(1): 44-53.

Assimopoulou, A.N., Andrikopoulos, N.K., Kaliora, A.C. \& Papageorgiou, V.P. 2002. Inhibitory activity of minor polyphenolic and nonpolyphenolic constituents of olive oil against in vitro low-density lipoprotein oxidation. Journal of Medicinal Food 5(1): 1-7.

Banks, W.A., Farr, S.A. \& Morley, J.E. 2000. Permeability of the blood-brain barrier to albumin and insulin in the young and aged SAMP8 mouse. Journals of Gerontology Series A Biological Sciences and Medical Sciences 55(12): B601-B606.

Batarseh, Y.S., Mohamed, L.A., Al Rihani, S.B., Mousa, Y.M., Siddique, A.B., El Sayed, K.A. \& Kaddoumi, A. 2017. Oleocanthal ameliorates amyloid- $\beta$ oligomers' toxicity on astrocytes and neuronal cells: In vitro studies. Neuroscience 352: 204-215.

Bisson, J.I., Cosgrove, S., Lewis, C. \& Roberts, N.P. 2015 . Posttraumatic stress disorder. The BMJ 351: h6161. doi: https:// doi.org/10.1136/bmj.h6161.

Boskou, D., Blekas, G. \& Tsimidou, M. 2006. Olive oil composition. In Olive Oil Chemistry and Technology. 2nd ed., edited by Boskou, D. Champaign, Illinois: AOCS Press pp. 41-72.

Brown, R., Lockwood, A.H. \& Sonawane, B.R. 2005. Neurodegenerative diseases: An overview of environmental risk factors. Environmental Health Perspectives 113(9): 1250-1256.

Budin, S.B., Othman, F., Louis, S.R., Bakar, M.A., Das, S. \& Mohamed, J. 2009. The effects of palm oil tocotrienolrich fraction supplementation on biochemical parameters, oxidative stress and the vascular wall of streptozotocininduced diabetic rats. Clinics 64(3): 235-244.

Cerf, E., Gustot, A., Goormaghtigh, E., Ruysschaert, J.M. \& Raussens, V. 2011. High ability of apolipoprotein E4 to stabilize amyloid- peptide oligomers, the pathological entities responsible for Alzheimer's disease. The FASEB Journal 25(5): 1585-1595.

Chawla, A., Chawla, R. \& Jaggi, S. 2016. Microvasular and macrovascular complications in diabetes mellitus: Distinct or continuum? Indian Journal of Endocrinology and Metabolism 20(4): 546-551.

De La Cruz, J.P., Del Río, S., López-Villodres, J.A., Villalobos, M.A., Jebrouni, N. \& González-Correa, J.A. 2010. Virgin olive oil administration improves the effect of aspirin on retinal vascular pattern in experimental diabetes mellitus. British Journal of Nutrition 104(4): 560-565.

Dewapriya, P., Himaya, S.W.A., Li, Y.X. \& Kim, S.K. 2013. Tyrosol exerts a protective effect against dopaminergic neuronal cell death in in vitro model of Parkinson's disease. Food Chemistry 141(2): 1147-1157.

EFSA Panel on Dietetic Products, Nutrition and Allergies (NDA). 2011. Scientific opinion on the substantiation of health claims related to polyphenols in olive and protection of LDL particles from oxidative damage (ID 1333, 1638, 1639, 1696, 2865), maintenance of normal blood HDL cholesterol concentrations (ID 1639), maintenance of normal blood pressure (ID 3781), “anti-inflammatory properties”(ID 1882),“contributes to the upper respiratory tract health"(ID 3468), "can help to maintain a normal function of gastrointestinal tract"(3779), and "contributes to body defences .... EFSA Journal 9(4): 2033. 
El, S.N. \& Karakaya, S. 2009. Olive tree (Olea europaea) leaves: Potential beneficial effects on human health. Nutrition Reviews 67(11): 632-638.

Esmaeili, A.K., Taha, R.M., Mohajer, S. \& Banisalam, B. 2016. In vitro regeneration and comparison of phenolic content, antioxidant and antityrosinase activity of in vivo and in vitro grown Asparagus officinalis. Sains Malaysiana 45(3): 373-381.

Feng,Z.,Li, X., Lin, J.,Zheng, W., Hu, Z., Xuan, J., Ni, W. \& Pan, X. 2017. Oleuropein inhibits the IL-1 $\beta$-induced expression of inflammatory mediators by suppressing the activation of $\mathrm{NF}-\mathrm{\kappa B}$ and MAPKs in human osteoarthritis chondrocytes. Food Funct. 8(10): 3737-3744.

González-Correa, J.A., Navas, M.D., Lopez-Villodres, J.A., Trujillo, M., Espartero, J.L. \& de La Cruz, J.P. 2008. Neuroprotective effect of hydroxytyrosol and hydroxytyrosol acetate in rat brain slices subjected to hypoxia-reoxygenation. Neuroscience Letters 446(2-3): 143-146.

Hassanshahi, J., Zamani, M., Soleimani, M. \& Zamani, F. 2013. Neuroprotective effect of olive oil in the hippocampus CA1 neurons following ischemia: Reperfusion in mice. Journal of Neurosciences in Rural Practice 4(2): 164-170.

Impellizzeri, D., Esposito, E., Mazzon, E., Paterniti, I., Di Paola, R., Bramanti, P., Morittu, V.M., Procopio, A., Perri, E., Britti, D. \& Cuzzocrea, S. 2012. The effects of a polyphenol present in olive oil, oleuropein aglycone, in an experimental model of spinal cord injury in mice. Biochemical Pharmacology 83(10): 1413-1426.

Kaeidi, A., Esmaeili-Mahani, S., Sheibani, V., Abbasnejad, M., Rasoulian, B., Hajializadeh, Z. \& Afrazi, S. 2011. Olive (Olea europaea $\mathrm{L}$.) leaf extract attenuates early diabetic neuropathic pain through prevention of high glucose-induced apoptosis: In vitro and in vivo studies. Journal of Ethnopharmacology 136(1): 188-196.

Khalatbary, A.R. \& Ahmadvand, H. 2012. Neuroprotective effect of oleuropein following spinal cord injury in rats. Neurological Research 34(1): 44-51.

Khalatbary, A.R. \& Zarrinjoei, G.R. 2012. Anti-inflammatory effect of oleuropein in experimental rat spinal cord trauma. Iranian Red Crescent Medical Journal 14(4): 229-234.

Kumar, J., Teoh, S.L., Das, S. \& Mahakknaukrauh, P. 2017. Oxidative stress in oral diseases: Understanding its relation with other systemic diseases. Frontiers in Physiology 8: 693.

Lee, B., Shim, I., Lee, H. \& Hahm, D.H. 2017. Effect of oleuropein on cognitive deficits and changes in hippocampal brain-derived neurotrophic factor and cytokine expression in a rat model of post-traumatic stress disorder. Journal of Natural Medicines 72(1): 44-56.

Lee, C.Y.D., Tse, W., Smith, J.D. \& Landreth, G.E. 2012. Apolipoprotein $\mathrm{E}$ promotes amyloid trafficking and degradation by modulating microglial cholesterol levels. Journal of Biological Chemistry 287(3): 2032-2044.

Leonelli, E., Bianchi, R., Cavaletti, G., Caruso, D., Crippa, D., Garcia-Segura, L.M., Lauria, G., Magnaghi, V., Roglio, I. \& Melcangi, R.C. 2007. Progesterone and its derivatives are neuroprotective agents in experimental diabetic neuropathy: A multimodal analysis. Neuroscience 144(4): 1293-1304.

Lotharius, J. \& Malley, K.L. 2000. The Parkinsonism-inducing drug 1-methyl-4-phenylpyridinium triggers intracellular dopamine oxidation: A novel mechanism of toxicity. Journal of Biological Chemistry 275(49): 38581-38588.

Luccarini, I., Ed Dami, T., Grossi, C., Rigacci, S., Stefani, M. \& Casamenti, F. 2014. Oleuropein aglycone counteracts A $\beta 42$ toxicity in the rat brain. Neuroscience Letters 558: 67-72.
Luceri, C., Bigagli, E., Pitozzi, V. \& Giovannelli, L. 2017. A nutrigenomics approach for the study of anti-aging interventions: Olive oil phenols and the modulation of gene and microRNA expression profiles in mouse brain. European Journal of Nutrition 56(2): 865-877.

Mardookhi, J., Bigdeli, M.R. \& Khaksar, S. 2016. The effect of pre-treatment with olive oil on TNFR1/NF-кB inflammatory pathway in rat ischemic stroke model. Physiology and Pharmacology 20(4): 246-255.

Mastantuono, T., Battiloro, L., Sabatino, L., Chiurazzi, M. Di Maro, M., Muscariello, E., Colantuoni, A. \& Lapi, D. 2015. Effects of citrus flavonoids against microvascular damage induced by hypoperfusion and reperfusion in rat pial circulation. Microcirculation 22(5): 378-390.

Matough, F.A., Budin, S.B., Hamid, Z.A., Alwahaibi, N. \& Mohamed, J. 2012. The role of oxidative stress and antioxidants in diabetic complications. Sultan Qaboos University Medical Journal 12(1): 5.

Mohagheghi, F., Bigdeli, M.R., Rasoulian, B., Hashemi, P. \& Pour, M.R. 2011. The neuroprotective effect of olive leaf extract is related to improved blood-brain barrier permeability and brain edema in rat with experimental focal cerebral ischemia. Phytomedicine 18(2-3): 170-175.

Oxford Dictionaries, s.v. “cognition". https://en.oxforddictionaries. com/definition/cognition. Accessed March 18, 2018.

Parkinson, L. \& Cicerale, S. 2016. The health benefiting mechanisms of virgin olive oil phenolic compounds. Molecules (Basel, Switzerland) 21(12): 1-12.

Poulsen, H., Trial, A.R., Mursu, J. \& Ba, H. 2006. The effect of polyphenols in olive oil on heart disease risk factors: A randomized trial. Annals of Internal Medicine 145(5): 333-341.

Pourkhodadad, S., Alirezaei, M., Moghaddasi, M., Ahmadvand, H., Karami, M., Delfan, B. \& Khanipour, Z. 2016. Neuroprotective effects of oleuropein against cognitive dysfunction induced by colchicine in hippocampal CA1 area in rats. Journal of Physiological Sciences 66(5): 397-405.

Qosa, H., Mohamed, L.A., Batarseh, Y.S., Alqahtani, S., Ibrahim, B., LeVine, H., Keller, J.N. \& Kaddoumi, A. 2015. Extravirgin olive oil attenuates amyloid- $\beta$ and tau pathologies in the brains of TgSwDI mice. Journal of Nutritional Biochemistry 26(12): 1479-1490.

Ristagno, G., Fumagalli, F., Porretta-Serapiglia, C., Orrù A., Cassina, C., Pesaresi, M., Masson, S., Villanova, L., Merendino, A., Villanova, A., Cervo, L., Lauria, G., Latini, R. \& Bianchi, R. 2012. Hydroxytyrosol attenuates peripheral neuropathy in streptozotocin-induced diabetes in rats. Journal of Agricultural and Food Chemistry 60(23): 5859-5865

Ruszymah, B.H.I., Chowdhury, S.R., Manan, N.A.B.A., Fong, O.S., Adenan, M.I. \& Saim, A.B. 2012. Aqueous extract of Centella asiatica promotes corneal epithelium wound healing in vitro. Journal of Ethnopharmacology 140(2): 333-338.

Sarbishegi, M., Charkhat Gorgich, E.A., Khajavi, O., Komeili, G. \& Salimi, S. 2018. The neuroprotective effects of hydroalcoholic extract of olive (Olea europaea L.) leaf on rotenoneinduced Parkinson's disease in rat. Metabolic Brain Disease 33(1): 79-88.

St-Laurent-Thibault, C., Arseneault, M., Longpre, F. \& Ramassamy, C. 2011. Tyrosol and hydroxytyrosol two main components of olive oil, protect $\mathrm{N} 2 \mathrm{a}$ cells against amyloid- $\beta$-induced toxicity. Involvement of the NF- $\kappa B$ signaling. Current Alzheimer Research 8(5): 543-551. 
Valls-Pedret, C., Lamuela-Raventós, R.M., Medina-Remón, A., Quintana, M., Corella, D., Pintó, X., Martínez-González, M.Á., Ramon, E. \& Emilioa, R. 2012. Polyphenol-rich foods in the mediterranean diet are associated with better cognitive function in elderly subjects at high cardiovascular risk. Journal of Alzheimer's Disease 29(4): 773-782.

Visioli, F. \& Galli, C. 1998. Olive oil phenols and their potential effects on human health. Journal of Agricultural and Food Chemistry 46(10): 4292-4296.

Wolman, M., Klatzo, I., Chui, E., Wilmes, F., Nishimoto, K., Fujiwara, K. \& Spatz, M. 1981. Evaluation of the dye-protein tracers in pathophysiology of the blood-brain barrier. Acta Neuropathologica 54(1): 55-61.

Yu, G., Deng, A., Tang, W., Ma, J., Yuan, C. \& Ma, J. 2016. Hydroxytyrosol induces phase II detoxifying enzyme expression and effectively protects dopaminergic cells against dopamine- and 6-hydroxydopamine induced cytotoxicity. Neurochemistry International 96: 113-120.

Khidhir Kamil, Jaya Kumar \& Ruszymah binti Haji Idrus* Department of Physiology

Faculty of Medicine

UKM Medical Centre

Jalan Yaacob Latif, Bandar Tun Razak

56000 Cheras , Kuala Lumpur, Federal Territory

Malaysia
Muhammad Dain Yazid

Tissue Engineering Centre

Faculty of Medicine

UKM Medical Centre

Jalan Yaacob Latif, Bandar Tun Razak

56000 Cheras, Kuala Lumpur, Federal Territory

Malaysia

*Corresponding author; email: ruszyidrus@gmail.com

Received: 30 March 2018

Accepted: 30 July 2018 